\title{
RESEARCH
}

Open Access

\section{Knowledge, attitude, and practice towards COVID-19 among chronic disease patients at Aksum Hospital, Northern Ethiopia, 2020: a cross-sectional study}

\author{
Assefa Iyasu* (D, Berihu Hailu Kidanu and Kidane Zereabruk
}

\begin{abstract}
Background: The Coronavirus disease 2019 outbreak is the first reported case in Wuhan, China in December 2019 and suddenly became a major global health concern. Currently, there is no vaccine and treatment have been reported. The aim of this study was to assess the knowledge, attitude, and practice of COVID-19 among chronic disease patients.

Methods: A hospital-based cross-sectional study was conducted among 422 chronic disease patients from July 01 to August 30, 2020 at Aksum Hospital, Northern Ethiopia. Both bivariable and multivariable logistic regression analyses with 95\% confidence intervals were fitted to identify factors associated with poor knowledge and practice towards COVID-19. The adjusted odds ratio (AOR) was used to determine the prevalence of the association between the dependent and independent variables. A $P$-value $<0.05$ was identified as statistically significant.

Results: A total of 422 participants participated in this study, with a $100 \%$ response rate. The prevalence of poor knowledge, poor practice and unfavorable attitude was 35.1, 48.8, and 40.5\%, respectively. Age (AOR =1.5, 95\% Cl: $(1.411,2.432))$, educational status of "can't read and write" (AOR $=1.4,95 \% \mathrm{Cl}:(1.332,9.612))$, and rural residence $(A O R=3.12,95 \% \mathrm{Cl}:(2.568,11.532))$ were significantly associated with poor knowledge. Educational status of "can't read and write" (AOR $=2.7,95 \% \mathrm{Cl}(1.03-7.29)$ ), and rural residence $(A O R=2.7,95 \% \mathrm{Cl}(1.09-6.70)$ ) were significantly associated with poor practice.

Conclusions: The prevalence of poor knowledge and poor practice among chronic disease patients were high. Rural residence and educational status with "can not read and write" were significantly associated with poor knowledge and poor practice. Older age was significantly associated with poor knowledge.
\end{abstract}

Keywords: COVID-19, Knowledge, Attitude, Practice, Chronic disease

* Correspondence: assie.iyasu@gmail.com

School of Nursing, Aksum University, PO. box 298, Aksum City, Tigray,

Ethiopia

(c) The Author(s). 2021 Open Access This article is licensed under a Creative Commons Attribution 4.0 International License, which permits use, sharing, adaptation, distribution and reproduction in any medium or format, as long as you give appropriate credit to the original author(s) and the source, provide a link to the Creative Commons licence, and indicate if changes were made. The images or other third party material in this article are included in the article's Creative Commons licence, unless indicated otherwise in a credit line to the material. If material is not included in the article's Creative Commons licence and your intended use is not permitted by statutory regulation or exceeds the permitted use, you will need to obtain permission directly from the copyright holder. To view a copy of this licence, visit http://creativecommons.org/licenses/by/4.0/ The Creative Commons Public Domain Dedication waiver (http://creativecommons.org/publicdomain/zero/1.0/) applies to the data made available in this article, unless otherwise stated in a credit line to the data. 


\section{Introduction}

An outbreak of pneumonia caused by a novel coronavirus occurred in Wuhan, Hubei province, in December 2019 and has spread rapidly throughout China [1].

On January 30, 2020, the World Health Organization (WHO) declared the outbreak a Public Health Emergency of International Concern and on February 12, 2020 , the WHO named the disease caused by the novel coronavirus "coronavirus disease 2019" (COVID-19) [2].

The current COVID-19 pneumonia pandemic, caused by the severe acute respiratory syndrome coronavirus 2 (SARS-CoV-2) is spreading globally at an accelerated rate [3].

Six months after the outbreak of COVID-19 in Wuhan City, China, and about three months after the WHO declared it a pandemic, the disease had infected nearly 8 million people and killed more than 433 thousand globally [4].

Because of the high volume of air traffic and trade between China and Africa, Africa is at a high risk for the introduction and spread of COVID-19 [5]; although only Egypt has reported the first case on Feb 14, 2020 [6].

By June 30, 2020, approximately 16.3 million people in Africa will contract COVID-19 [7]. On 13 March, 2020, Ethiopia confirmed its first case of COVID-19 and on 26 June, 2020, tested 237,464 suspects, of whom 5425 (2.3\%) cases had been confirmed positive and Outof the confirmed positive about $89(1.6 \%)$ died and 1688 (31.1\%) recovered [8].

Most of the fatal cases and severe illnesses like acute respiratory distress syndrome (ARDS) occur in aged and people who have underlying medical co-morbidities like diabetes, cancer, hypertension, heart, lung, and kidney diseases [9]. The spread of COVID-19 is still alarmingly increasing from day to day and is not controlled, even though there is health promotion, including hand washing and social distancing. Poor understanding of the disease among the community enhances the spread of infection and death. Therefore, successful prevention and minimization of morbidity and mortality due to COVID-19 require changing the behavior, which is influenced by individuals knowledge and attitude [10].

Therefore, understanding the "high-risk" groups, especially those with chronic disease, knowledge, attitude and practice (KAP) and possible risk factors is necessary and helps to anticipate the outcomes of planned behavior on COVID-19. Thus, this study aimed to determine the KAP towards COVID-19 and associated factors of poor knowledge and practice among chronic disease patients at Aksum Hospital. The results of this study in the early stages of the pandemic may help to direct the efforts and plans of public health authorities, clinicians, and the media of the country for better and timely control of COVID-19.

\section{Methods}

Study setting and period

A hospital-based cross-sectional study was conducted from July 01 to August 30, 2020, at Aksum Hospital in Aksum Town, Northern Ethiopia.

\section{Source and study population}

All patients with chronic diseases (hypertension, diabetes mellitus, heart disease, chronic lung disease, and other diseases) who attended the chronic disease follow-up clinics at Aksum Hospital were the sources of population, while all patients with chronic diseases who attended the chronic disease follow-up clinics at Aksum Hospital during the study period were the study population.

\section{Inclusion and exclusion criteria}

All chronic disease patients whose aged greater than 18 years who were on follow-up at the hospital during the study period were included whereas critically ill or had cognitive impairment and health professionals were excluded from this study.

\section{Sample size and sampling procedure}

The sample size was calculated using a single proportion formula, $\mathrm{n}=\frac{\left[\mathrm{Z} \frac{\mathrm{m}}{2}\right]^{2} \mathrm{p}(1-\mathrm{p})}{d^{2}}$ at $95 \%$ confidence level, where $\mathrm{Z}$ $\frac{\alpha}{2}=$ standard normal deviation (1.96), $\mathrm{d}=5 \%$ of marginal error, and $\mathrm{p}=$ prevalence $50 \%$. Since, there are no published data that show the knowledge, attitude, and practice of COVID-19 among chronic disease patients in Ethiopia.

$$
\mathrm{n}=\frac{(1.96) 2 \times 0.5(1-0.5)}{(0.05)^{2}}=384
$$

There of $10 \%$ of the sample size would add for the non-response rate so that it would be a 422 study subjects. A consecutive sampling method was employed to select the study participants.

\section{Data collection tools and procedures}

Prior to data collection pre-test was conducted on $10 \%$ of the study subjects which were 42 patients in Shire Hospital two weeks before the actual data collection period to ensure quality, clarity, understand and completeness of the data. The data were collected using a pre-tested, structured interviewer administered questionnaire. The questionnaire included socio-demographic and clinical characteristics and KAP towards COVID-19. Four BSc holder nurses were recruited for data collection and one MSc holder nurse was recruited as a supervisor by wearing a mask and glove in a well-ventilated room with a minimum distance of $2 \mathrm{~m}$ from the patients. 


\section{Operational definitions \\ Knowledge towards COVID-19}

The questionnaire regarding knowledge was sixteen questions (with minimum score 0 and maximum score 16); were answered on a yes/no basis and an additional "I don't know" option. A correct answer was given 1 point and an incorrect/unknown answer was given 0 points. The total knowledge score ranged from 0 to 16 . Participants' overall knowledge was categorized using Bloom's cutoff point, as good if the score was between 80 and $100 \%$ (12.7-16 points), moderate if the score was between 60 and 79\%(9.6-12.6 points), and poor if the score was less than $60 \%$ (<9.6 points) [11].

\section{Practice towards COVID-19}

Similarly, the question regarding the practice was fifteen (with a minimum score of 0 and a maximum score of $15)$; were answered yes or no, the correct answer was given 1 point and an incorrect answer was given 0 points. The overall practice score was categorized using Bloom's cutoff point, as good if the score was between 80 and $100 \%$ (12-15 points), moderate if the score was between 60 and 79\% (9-11.9 points), and poor if the score was less than $60 \%$ ( $<9$ points) [11].

\section{Attitude towards COVID-19}

The question regarding attitude was eleven (with a minimum score of 11 and a maximum score of 55). The score of the attitude was based on 5 points Likert scale, in which a score of 1 to 5 was given from strongly disagree to strongly agree. A mean score $>33$ (answering strongly agree or agree) was carried out as a favorable e attitude and a score of 11 to 33 indicated an unfavorable attitude (answering strongly disagree or disagree or neutral) $[12,13]$.

\section{Data quality assurance}

To assure the quality of data, a pretest was done on $10 \%$ of the subjects in Shire hospital having similar sociodemographic characteristics two weeks before the actual data collection. The reliability of the knowledge, attitude, and practice questionnaires were checked and the values of Cronbach's alpha were $0.855,0.793$, and 0.795 , respectively, indicating acceptable internal consistency [14]. Four BSC nurses and two supervisors were recruited for data collection and training was given. The collected data were checked by a supervisor and principal investigator daily.

\section{Data processing and analysis}

After data collection, the data were entered in to Epidata 3.1 and exported to the SPSS version 22 statistical package for analysis. Descriptive characteristics are presented in the text, frequency percentage tables, and graphs. A binary logistic regression model was used to identify factors associated with poor knowledge and poor practice. Then, variables that were found to have an association with the outcome variable at $P<0.25$ was used in multivariable logistic regression. Finally, a $P$-value $<0.05$ was describe as a statistically associated with a $95 \%$ confidence level.

\section{Results \\ Socio-demographic and clinical characteristics}

Overall, 422 participants were included in this study, with a response rate of $422(100 \%)$. Of the total participants, 220(52.1\%) were female and the remaining were male. The mean age of the participants was (32.99 $\pm(6.325)$ SD years) and whose age of 50-92 participants was $185(43.8 \%)$. Of the participants, 416(98.6\%) and 6(1.4\%) were Tigrian and Amhara, respectively. Of the total participants, 268(63.5\%) were married. Regarding educational status, 182(43.1\%) of the study participants could not read and write, while $133(31.5 \%)$ could read and write. Of the total participants, 332(78.7\%) were from an urban area. Of the study participants, 104 (24.6\%), 95 (22.5\%), and 90 (21.3\%) were diabetes, hypertension and chronic lung disease, respectively (Table 1 ).

\section{Knowledge towards COVID-19}

The prevalence of poor knowledge was 35.1\% (95\% CI (27.6-39.3\%). About 102 (24.2\%) study participants reported that COVID-19 symptoms appeared within 2-14 days. "Persons with COVID-19 cannot infect the virus to others if they have no any symptoms of COVID-19", "washing hands frequently with soap and water for at least 20 seconds or use an alcohol-based hand sanitizer $(60 \%)$ is important to prevent infection with COVID19 ", "isolation and treatment of people who are infected with the COVID-19 virus are effective ways to reduce the spread of the virus" by 336(55.9\%), 320(75.8\%), and $330(78.2 \%)$ of the study participants, respectively. People who have contact with someone infected with the COVID-19 virus should be immediately isolated in a proper place by $258(61.1 \%)$ participants. Most $310(73.5 \%)$ of the study participants reported that wearing masks when moving out of home is important to prevent infection with COVID-19 virus. Most 350 (82.9\%) of the study participants reported that avoiding going to crowded places such as public transportations, religious places, hospitals and workplaces to prevent COVID-19 infection (Table 2).

Associated factors of poor knowledge towards COVID-19 Crude associations of socio-demographic variables with poor knowledge were checked and age, educational status, 
Table 1 Socio-demographic and Clinical Characteristics of Chronic Disease Patients, Aksum Hospital, Northern Ethiopia, $2020(N=422)$

\begin{tabular}{|c|c|c|}
\hline Variable & Category & $\begin{array}{l}\text { Frequency } \\
\mathrm{N}(\%)\end{array}$ \\
\hline \multirow[t]{3}{*}{ Age } & $18-34$ years & $73(17.3)$ \\
\hline & $35-49$ years & 164(38.9) \\
\hline & 50-92 years & 185(43.8) \\
\hline \multirow[t]{2}{*}{ Sex } & Male & $202(47.9)$ \\
\hline & Female & $220(52.1)$ \\
\hline \multirow[t]{2}{*}{ Residence } & Urban & $332(78.7)$ \\
\hline & Rural & $90(21.3)$ \\
\hline \multirow[t]{4}{*}{ Marital status } & Single & $21(5)$ \\
\hline & Married & $268(63.5)$ \\
\hline & Divorced & $44(10.4)$ \\
\hline & Widowed & $89(21.1)$ \\
\hline \multirow[t]{2}{*}{ Ethnicity } & Amhara & $6(1.4)$ \\
\hline & Tigray & 416(98.6) \\
\hline \multirow[t]{4}{*}{ Educational status } & Un able to write read & 182(43.1) \\
\hline & Able to write and read & 133(31.5) \\
\hline & Primary school & $47(11.3)$ \\
\hline & Secondary and above & $60(14.2)$ \\
\hline \multirow[t]{7}{*}{ Occupation } & House wife & $78(18.5)$ \\
\hline & Private business & $90(21.3)$ \\
\hline & Government employee & $54(12.8)$ \\
\hline & Farmer & $95(22.5)$ \\
\hline & Unemployed & $62(14.7)$ \\
\hline & Daily labourer & $10(2.4)$ \\
\hline & Retired & $33(7.8)$ \\
\hline \multirow[t]{5}{*}{ Type of chronic Disease } & Diabetes mellitus & 104(24.6) \\
\hline & Hypertension & $95(22.5)$ \\
\hline & Heart Disease & $110(26.1)$ \\
\hline & Chronic lung disease & $90(21.3)$ \\
\hline & Other $^{a}$ & 23(5.4) \\
\hline \multirow{6}{*}{$\begin{array}{l}\text { High-risk group for } \\
\text { developing severe illness }\end{array}$} & Old age(elderly) & $200(47.4)$ \\
\hline & $\begin{array}{l}\text { DM or HTN or Heart } \\
\text { disease co-morbidity }\end{array}$ & 150(35.5) \\
\hline & Suppressed immunity & $40(9.5)$ \\
\hline & Chronic lung diseases & $20(4.7)$ \\
\hline & Children & $5(1.2)$ \\
\hline & Pregnant & $7(1.7)$ \\
\hline
\end{tabular}

Notes: a HIV; Rheumatoid arthritis, age category [15]

marital status, residence, and occupation were statistically significant at $p<0.25$. These variables having significant crude associations were entered into the multivariable logistic regression model. Accordingly, age, rural residence, educational status of "can't read and write" were significantly associated with poor knowledge at $p<0.05$.
This study showed that whose age of a 50-90 years old was 1.5 times more likely to be associated with poor knowledge than those aged a $18-34$ years $(\mathrm{AOR}=1.5$, 95\% CI: $(1.411,2.432))$. This study also showed that participants who "can't read and write" had 8.5 times more likely associated to poor knowledge than with an educational status of "secondary and above" (AOR $=8.52,95 \%$ CI: (5.241, 23.543)), and the odds of having poor knowledge in rural residents were seven times $(\mathrm{AOR}=7.21$, 95\% CI: $(6.763,13.392)$ ) (Table 3).

\section{Attitude of chronic disease patients toward COVID-19}

The prevalence of unfavorable attitudes was $40.5 \%$ (95\% CI (32.1-46.4\%). Most 302(71.6\%) of the study participants strongly disagree with the statement "Ethiopia can win the battle against the COVID-19 virus". Two hundred forty five $(58.1 \%)$ had agree with "worried one of your family members may get an infection". Among the study participants, "Prevalence of COVID-19 can be reduced by the active participant of health care workers in hospital infection control programs" 155(36.7\%), "if a COVID-19 vaccine was available, I would have it" 316(74.9\%), and "Patients should disclose their exposure" 381(90.3\%) agreed, strongly agree, and strongly disagree, respectively (Table 4).

\section{Infection prevention practice towards COVID- 19}

The prevalence of poor practice was $48.8 \%$ (95\% CI (40.1-57.6\%). The majority (90.8\%) of the participants reuse a mask. Only one-third (33.4\%) of the study participants wore a mask when leaving home to prevent COVID-19 infection. Avoiding participates in meetings, religious activities, events, and other social gatherings and frequently washing hands with soap and water for at least $20 \mathrm{~s}$ or using sanitizers were (37.7\%), and (64.5\%) respectively. The other less frequently practiced preventive measures were did not use other workers' phones, desks, offices, or other work tools (20.4\%), and "physical distancing" by the remaining $6 \mathrm{ft} / 2 \mathrm{~m}$ away from others (28.4\%) (Table 5).

\section{Associated factors of poor practice towards COVID-19}

Crude associations of socio-demographic variables with poor practice were checked and age, educational status, and residence were statistically significant at $p<0.25$. These variables having significant crude associations were entered into the multivariable logistic regression model. Accordingly, rural residence, and educational status of "can't read and write" were significantly associated with poor practice at $p<0.05$. The odds of poor practice in rural residents of study participants were three times $(\mathrm{AOR}=3.12,95 \% \mathrm{CI}:(2.568,11.532))$ more likely to be associated than with urban residents. This study also showed that participants who "can't read and write" had 
Table 2 Knowledge of chronic disease patients, Aksum Hospital, Northern Ethiopia, 2020 (N=422)

\begin{tabular}{|c|c|c|c|c|}
\hline \multirow{2}{*}{$\begin{array}{l}\text { Serial } \\
\text { Number }\end{array}$} & \multirow[t]{2}{*}{ Knowledge Questions } & \multicolumn{3}{|c|}{ Frequency (\%) } \\
\hline & & $\begin{array}{l}\text { Yes } N \\
(\%)\end{array}$ & No $\mathbf{N}(\%)$ & $\begin{array}{l}\text { I don't know } \\
\mathrm{N}(\%)\end{array}$ \\
\hline 1. & Main clinical symptoms of COVID-19 are fever, cough, shortness of breath, and fatigue & $\begin{array}{l}389 \\
(92.2)\end{array}$ & $11(2.6)$ & $22(5.2)$ \\
\hline 2. & $\begin{array}{l}\text { Unlike the common cold, stuffy nose, runny nose, and sneezing are less common in persons } \\
\text { infected with the COVID-19 virus }\end{array}$ & $\begin{array}{l}150 \\
(35.6)\end{array}$ & $206(48.8)$ & $66(15.6)$ \\
\hline 3. & COVID-19 symptoms appear within 2-14 days & $\begin{array}{l}102 \\
(24.2)\end{array}$ & $24(5.7)$ & $297(70.1)$ \\
\hline 4. & $\begin{array}{l}\text { Currently, there is no effective treatment or vaccine for COVID-19, but early symptomatic and } \\
\text { supportive treatment can help most patients to recover from the infection }\end{array}$ & $300(71.1)$ & $3(0.7)$ & $119(28.2)$ \\
\hline 5. & $\begin{array}{l}\text { Not all persons with COVID-19 will develop severe cases. Those who are elderly, have chronic } \\
\text { illnesses, and with suppressed immunity are more likely to be severe cases }\end{array}$ & $\begin{array}{l}302 \\
(71.5)\end{array}$ & $18(4.3)$ & 102(24.2) \\
\hline 6. & $\begin{array}{l}\text { Touching or shaking hands of an infected person would result in the infection by the } \\
\text { COVID-19 virus }\end{array}$ & $\begin{array}{l}286 \\
(67.8)\end{array}$ & $42(9.9)$ & $94(22.3)$ \\
\hline 7. & $\begin{array}{l}\text { Touching an object or surface with the virus on it, then touching your mouth, nose, or eyes } \\
\text { with the unwashed hand would result in the infection by the COVID-19 virus }\end{array}$ & $\begin{array}{l}222 \\
(52.6)\end{array}$ & $85(20.1)$ & $115(27.3)$ \\
\hline 8. & $\begin{array}{l}\text { The COVID-19 virus spreads via respiratory droplets of infected individuals through the air } \\
\text { during sneezing or coughing of infected patients }\end{array}$ & $\begin{array}{l}357 \\
(84.6)\end{array}$ & 13(3.1) & $52(12.3)$ \\
\hline 9. & $\begin{array}{l}\text { Persons with COVID-19 cannot infect the virus to others if he has no any symptom of } \\
\text { COVID-19 }\end{array}$ & $236(55.9)$ & $86(20.4)$ & $100(23.7)$ \\
\hline 10. & $\begin{array}{l}\text { Wearing masks when moving out of home is important to prevent the infection with } \\
\text { COVID-19 virus }\end{array}$ & $\begin{array}{l}310 \\
(73.5)\end{array}$ & $27(6.4)$ & $85(20.1)$ \\
\hline 11. & $\begin{array}{l}\text { Children and young adults do not need to take measures to prevent the infection by the } \\
\text { COVID-19 virus }\end{array}$ & 130(30.8) & $200(47.4)$ & $92(21.8)$ \\
\hline 12. & $\begin{array}{l}\text { To prevent the COVID-19 infection, individuals should avoid going to crowded places such } \\
\text { as } \\
\text { public transportations, religious places, Hospitals and Workplaces }\end{array}$ & $350(82.9)$ & $12(2.8)$ & $60(14.2)$ \\
\hline 13. & $\begin{array}{l}\text { Washing hands frequently with soap and water for at least } 20 \mathrm{~s} \text { or use an alcohol based } \\
\text { hand sanitizer (60\%) is important to prevent infection with COVD-19 }\end{array}$ & $320(75.8)$ & $40(9.5)$ & $62(14.7)$ \\
\hline 14. & $\begin{array}{l}\text { Traveling to an infectious area or having contact with someone traveled to an area where } \\
\text { the infection present is a risk for developing an infection }\end{array}$ & $400(94.8)$ & $1(0.24)$ & $21(5)$ \\
\hline 15. & $\begin{array}{l}\text { Isolation and treatment of people who are infected with the COVID-19 virus are effective } \\
\text { ways to reduce the spread of the virus }\end{array}$ & $330(78.2)$ & $17(4)$ & 75(17.8) \\
\hline 16. & $\begin{array}{l}\text { People who have contact with someone infected with the COVID-19 virus should be } \\
\text { immediately isolated in a proper place. }\end{array}$ & $258(61.1)$ & $32(7.6)$ & $132(31.3)$ \\
\hline
\end{tabular}

1.4 times $(\mathrm{AOR}=1.4,95 \% \mathrm{CI}:(1.332,9.612))$ more likely associated to poor practice than with an educational status of "secondary and above" (Table 6).

\section{Discussion}

Presently, COVID-19 has spread rapidly throughout different countries and has become a major global health concern. Consequently, understanding the 'high-risk groups' especially those with chronic disease, KAP and possible risk factors is necessary to prevent and control the pandemic disease of COVID-19.

According to this study, the prevalence of poor knowledge was (35.1\%). This finding is higher than that of the study done in Iran (20.4\%) [16] and China (10\%) [17], which stated a low prevalence of poor knowledge. This might be due to a difference in the socio-economic status of study participants (in rural
Ethiopia had no access to internet and electricity [18] and this results limited access of updated information related to COVID-19), differences in assessment tool used for knowledge and time of data collection.

According to this study, older age was found to be associated with poor knowledge. This is in line with a study done in Chicago [19] and Hubei Province [17]. This might be physiologically happened during aging like decrease hearing and visual ability. So, thus makes confront to read different health related issues and results poor knowledge.

This study showed that rural residents had seven times more likely associated to poor knowledge than urban residents. This finding is consistent with a study in China [17]. This might be due to there is no electricity and internet in rural areas and had lack of access to information, results poor knowledge. In addition, rural residents in Ethiopia are largely 
Table 3 Factors associated with poor knowledge among chronic disease patients in bivariable and multivariable logistic regression analyses, Aksum Hospital, Northern Ethiopia, 2020 ( $N=422)$

\begin{tabular}{|c|c|c|c|c|c|c|}
\hline \multirow[t]{2}{*}{ Variable } & \multirow[t]{2}{*}{ Category } & \multicolumn{2}{|c|}{ Poor knowledge } & \multicolumn{3}{|l|}{ OR $(95 \% \mathrm{Cl})$} \\
\hline & & Yes $(n=148)$ & No $(n=274)$ & COR & $P$-value & AOR \\
\hline \multirow[t]{3}{*}{ Age } & $18-34$ years & $10(13.7)$ & 63(86.3) & 1 & & 1 \\
\hline & $35-49$ years & $37(22.6)$ & $127(77.4)$ & $0.544(0.451,2.097)$ & 0.056 & $1.922(0.937,3.939)$ \\
\hline & $50-92$ years & 101(54.6) & $84(45.4)$ & $0.132(0.101,1.209)^{*}$ & 0.03 & $1.5(1.411,2.432)^{* *}$ \\
\hline \multirow[t]{2}{*}{ Sex } & Male & $81(40.1)$ & $121(59.9)$ & 1 & & \\
\hline & Female & $67(30.5)$ & $153(69.5)$ & $1.52(0.821,1.91)$ & & \\
\hline \multirow[t]{2}{*}{ Ethnicity } & Amhara & $2(33.3)$ & $4(66.7)$ & 1 & & \\
\hline & Tigray & $146(35.1)$ & $270(64.9)$ & $0.924(0.821,2.652)$ & & \\
\hline \multirow[t]{2}{*}{ Residence } & Urban & $66(19.9)$ & $266(80.1)$ & 1 & & 1 \\
\hline & Rural & $82(92.2)$ & $8(8.8)$ & $0.024(0.017,6.051)^{*}$ & 0.027 & $7.21(6.763,13.392)^{* *}$ \\
\hline \multirow[t]{4}{*}{ Educational level } & Un able to write and read & $110(60.4)$ & 72(39.6) & $13.75(11.453,57.893)^{*}$ & 0.006 & $8.52(5.241,23.543)^{* * *}$ \\
\hline & Able to write and read & $20(15)$ & $113(85)$ & $1.59(1.001,8.213)^{*}$ & 0.07 & $1.89(0.978,6.519)$ \\
\hline & Primary school & $12(25.5)$ & $35(74.5)$ & $3.08(0.941,9.196)$ & & $0.71(0.673,4.921)$ \\
\hline & Secondary and above & $6(10)$ & $54(90)$ & 1 & & 1 \\
\hline \multirow[t]{7}{*}{ Occupational status } & House wife & $32(40.1)$ & $46(58.9)$ & 1 & & \\
\hline & Private business & $14(15.6)$ & $76(84.4)$ & $3.77(2.064,4.751)$ & & \\
\hline & Government employee & $15(27.8)$ & $39(72.2)$ & $1.81(0.111,3.739)$ & & \\
\hline & Farmer & $45(47.4)$ & $50(52.6)$ & $0.77(0.482,8.235)$ & & \\
\hline & Unemployed & $27(43.5)$ & $35(56.5)$ & $0.9(0.261,5.94)$ & & \\
\hline & Daily laborer & $8(80)$ & $2(20)$ & $0.17(0.085,4.743)$ & & \\
\hline & Retired & $7(21.2)$ & $26(78.8)$ & $2.6(1.302,6.629)$ & & \\
\hline
\end{tabular}

Notes: ${ }^{*} p$-value $<0.25$, statistically significant in COR; ** $p$-value $<0.05$, statistically significant in AOR. Abbreviations: AOR adjusted odds ratio, Cl confidence interval, COR crude odds ratio. Age category [15]

Table 4 Attitude of chronic disease patients, Aksum hospital, Northern Ethiopia, $2020(N=422)$

\begin{tabular}{|c|c|}
\hline $\begin{array}{l}\text { Serial } \\
\text { Number }\end{array}$ & Questions \\
\hline 1. & $\begin{array}{l}\text { Do you agree that COVID-19 will finally be successfully } \\
\text { controlled? }\end{array}$ \\
\hline 2. & $\begin{array}{l}\text { Do you have confidence that Ethiopia can win the battle } \\
\text { against the COVID-19 virus? }\end{array}$ \\
\hline 3. & You think you will probably get the illness \\
\hline 4. & $\begin{array}{l}\text { You are worried one of your family members may get an } \\
\text { infection }\end{array}$ \\
\hline 5. & $\begin{array}{l}\text { If getting COVID-19, you will accept isolation in health } \\
\text { facilities }\end{array}$ \\
\hline 6. & $\begin{array}{l}\text { Transmission of COVID-19 can be prevented by washing } \\
\text { hands with soap frequently }\end{array}$ \\
\hline 7. & $\begin{array}{l}\text { Prevalence of COVID-19 can be reduced by the active } \\
\text { participant of health care workers in hospital infection } \\
\text { control programs }\end{array}$ \\
\hline 8. & If a COVID-19 vaccine was available, I would have it \\
\hline 9. & COVID-19 patients should be kept in isolation \\
\hline 10. & Patients should disclose their exposure \\
\hline $11 /$ & $\begin{array}{l}\text { Medical staffs are ready to participate in anti-epidemic in } \\
\text { the community }\end{array}$ \\
\hline
\end{tabular}

Attitude: Favorable 251(59.5\%)

Unfavorable 171(40.5\%)

Mean of attitude ( $33.9 \pm 11.6 \mathrm{SD})$ with a range of 12 to 55 uneducated and reduced ability to comprehend health information related to prevention of COVID-19.

This study reported that participants who "can't read and write" had 8.5 and 1.4 times more likely associated to poor knowledge and poor practice than with an educational status of "secondary and above" respectively. This finding is in line with a study in Bangladeshis [20]. This might be due to when "someone gets more educated he/she will have a better understanding of control measures and preventive strategies related to COVID19 ", and the capacity to practice recommendations to protect COVID-19 will rise. In addition, those who could read and write had an opportunity to get information through reading.

Upon this study, the prevalence of favorable attitude was $(59.5 \%)$. This finding is in line with a study in China and Iran $[13,21]$. This might be due to the same characteristics of the infection since this is respiratory distress disease.

In this study showed that about $71.6 \%$ of study participants strongly disagree with the statement "Ethiopia can win the battle against COVID-19 virus". This finding is higher than that of the study in China [17] which was around $5.3 \%$ strongly disagree with the statement of "China can win the battle against COVID-19 virus". This might be due to low traffic limits all throughout states of 
Table 5 Infection prevention practice of chronic disease patients toward COVID-19, Aksum Hospital, Northern Ethiopia, 2020 $(N=422)$

\begin{tabular}{|c|c|c|c|}
\hline \multirow{2}{*}{$\begin{array}{l}\text { Serial } \\
\text { Number }\end{array}$} & \multirow[t]{2}{*}{ Questions } & \multicolumn{2}{|l|}{ Frequency } \\
\hline & & Yes N (\%) & No $\mathrm{N}(\%)$ \\
\hline 1. & $\begin{array}{l}\text { Do you participate in meetings, religious activities, events, and other social gatherings or any crowded } \\
\text { place in areas with ongoing community transmission? }\end{array}$ & $263(62.3)$ & $159(37.7)$ \\
\hline 2. & In recent days, have you worn a mask when leaving home? & $141(33.4)$ & $281(66.6)$ \\
\hline 3. & If yes, do you touch the front of the mask when taking it off? & $121(85.8)$ & $20(14.2)$ \\
\hline 4. & Do you reuse a mask? & 128(90.8) & $13(9.2)$ \\
\hline 5. & Do you wash your hands with soap and water frequently for at least 20s or use sanitizer/60\% alcohol? & 272(64.5) & 150(35.5) \\
\hline 6. & Do you touch your eyes, nose, and mouth frequently with unwashed hands? & 123(29.1) & 299(70.9) \\
\hline 7. & Do you clean and disinfect frequently touched objects and surfaces? & 242(57.3) & 180(42.7) \\
\hline 8. & Do you practice "physical distancing" by remaining $6 \mathrm{ft} / 2 \mathrm{~m}$ away from others at all times? & $120(28.4)$ & $302(71.6)$ \\
\hline 9. & Do you use other workers' phones, desks, offices, or other work tools and equipment? & $336(79.6)$ & $86(20.4)$ \\
\hline 10. & Do you limit contact (such as handshakes)? & $312(73.9)$ & $110(26.1)$ \\
\hline 11. & Do you eat or drink in bars and restaurants? & 270(64) & $152(36)$ \\
\hline 12. & $\begin{array}{l}\text { Do you cover your nose and mouth during coughing or sneezing with the elbow or a tissue, and then throw } \\
\text { the tissue in the trash? }\end{array}$ & 299(70.9) & $123(29.1)$ \\
\hline 13. & Do you prefer to stay at home, in a room with the window open during the transmission period? & 133(31.5) & $289(68.5)$ \\
\hline 14. & Do you stay home when you were sick due to common cold-like infection during the transmission period? & 294(72.8) & $110(27.2)$ \\
\hline 15. & Do you listen and follow the direction of your state and local authorities? & 273(67.6) & $131(32.4)$ \\
\hline
\end{tabular}

Table 6 Factors associated with poor practice among chronic disease patients in bivariable and multivariable logistic regression analyses, Aksum Hospital, Northern Ethiopia, 2020 ( $N=422)$

\begin{tabular}{|c|c|c|c|c|c|c|}
\hline \multirow[t]{2}{*}{ Variable } & \multirow[t]{2}{*}{ Category } & \multicolumn{2}{|l|}{ Poor Practice } & \multicolumn{3}{|l|}{ OR $(95 \% \mathrm{Cl})$} \\
\hline & & Yes $(n=206)$ & No $(n=216)$ & COR & P-value & AOR \\
\hline \multirow[t]{3}{*}{ Age } & $18-34$ years & $30(41.1)$ & $43(58.9)$ & 1 & & 1 \\
\hline & $35-49$ years & $60(36.6)$ & 104(63.4) & $1.209(1.021,3.041)^{*}$ & 0.061 & $1.03(0.781,5.652)$ \\
\hline & 50-92 years & $116(62.7)$ & $69(37.3)$ & $0.415(0.321,1.209)^{*}$ & 0.058 & $1.8(0.921,3.432)$ \\
\hline \multirow[t]{2}{*}{ Sex } & Male & $90(44.6)$ & $112(55.4)$ & 1 & & \\
\hline & Female & $116(52.7)$ & 104(47.3) & $0.72(0.421,2.31)$ & & \\
\hline \multirow[t]{2}{*}{ Ethnicity } & Amhara & $1(16.7)$ & $5(83.3)$ & 1 & & \\
\hline & Tigray & 205(49.3) & $211(50.7)$ & $0.21(0.053,3.351)$ & & \\
\hline \multirow[t]{2}{*}{ Residence } & Urban & 130(39.2) & $202(60.8)$ & 1 & & 1 \\
\hline & Rural & $76(84.4)$ & 14(15.6) & $0.12(0.023,4.071)^{*}$ & 0.041 & $3.12(2.568,11.532)^{* *}$ \\
\hline \multirow[t]{4}{*}{ Educational level } & Un able to write and read & $110(60.4)$ & 72(39.6) & $2.1(1.361,11.323)^{*}$ & 0.02 & $1.4(1.332,9.612)^{* *}$ \\
\hline & Able to write and read & 48(36.1) & 85(63.9) & $0.79(0.459,6.341)^{*}$ & 0.09 & $0.7(0.045,4.325)$ \\
\hline & Primary school & 23(48.9) & 24(51.1) & $1,3(1.086,7.421)^{*}$ & 0.12 & $0.76(0.576,3971)$ \\
\hline & Secondary and above & $25(41.7)$ & 35(58.3) & 1 & & 1 \\
\hline \multirow[t]{7}{*}{ Occupational status } & House wife & 42(53.8) & $36(46.2)$ & 1 & & \\
\hline & Private business & $31(34.4)$ & $59(65.6)$ & $2.2(2.032,5.642)$ & & \\
\hline & Government employee & 16(29.6) & $38(70.4)$ & $2.7(2152,4.403)$ & & \\
\hline & Farmer & $65(68.4)$ & $30(31.6)$ & $0.54(0.262,9.421)$ & & \\
\hline & Unemployed & $38(61.3)$ & 24(38.7) & $0.74(0.432,6.592)$ & & \\
\hline & Daily laborer & $5(50)$ & $5(50)$ & $1.2(0.943,6.347)$ & & \\
\hline & Retired & $9(27.3)$ & $24(72.7)$ & $3.1(1.702,8.059)$ & & \\
\hline
\end{tabular}

Notes: ${ }^{*} p$-value $<0.25$, statistically significant in COR; ${ }^{* *} p$-value $<0.05$, statistically significant in AOR. Abbreviations: AOR adjusted odds ratio, $C l$ confidence interval, COR crude odds ratio. Age category [15] 
Ethiopia, and low socioeconomic status which decrease people's confidence in winning the battle against the COVID-19 virus.

According to this study, the prevalence of poor practice was high (48.8\%). This finding is higher than that of the study done in china [17]. This might be due to vary in sources of information, media exposure, knowledge, religious perspective, and application of governmental state of emergency.

According to this finding, rural residents had three times more likely associated to poor practice than urban residents. This is similar with a study done in China [17]. This might be due to the ways to access information in rural areas of Ethiopia are through family, friends and health care workers. When the health information is not delivered timely and resourcefully, the tendency of practicing such information is decreased.

\section{Conclusions}

The prevalence of poor knowledge and poor practice among chronic disease patients were high. Rural residence and educational status with "cannot read and write" were significantly associated with poor knowledge and poor practice. Older age was significantly associated with poor knowledge. The health care workers at the chronic outpatient department should provide detailed information about COVID-19 to their patients. The patients should get information about COVID-19 in their local languages.

\section{Abbreviations \\ ARDS: Acute Respiratory Distress Syndrome; COVID-19: CoronaVirus Disease in 2019; KAP: Knowledge Attitude and Practice; MSC: Masters of Science; \\ SARS: Severe Acute Respiratory Syndrome; SD: Standard Deviation; \\ SPSS: Statistical Package for the Social Science; WHO: World Health \\ Organization}

\section{Acknowledgments}

We would like to express our thanks to Aksum University school of Nursing Then, we would like to extend our appreciation to study participants, data collectors, and supervisor for their participation, cooperation, and willingness.

\section{Authors' contributions}

'Assefa lyasu Negash' contributes in conception, design, execution, acquisition of data, analysis and interpretation, drafting and writing the final manuscript. 'Berihu Hailu Kidanu' and 'Kidane Zereabruk': conceptualization, methodology, investigation, visualization, validation, critically reviewed the article. The authors read and approved the final manuscript to be published.

\section{Authors' information}

Assefa lyasu Negash, MSc in Adult Health Nursing, Lecturer in Aksum University.

Berihu Hailu Kidanu, MSc in Adult Health Nursing, Lecturer in Aksum University.

Kidane Zereabruk, MSc in Adult Health Nursing, Lecturer in Aksum University.

\section{Funding}

This research did not receive any specific grant from funding agencies in the public, commercial, or not-for-profit sectors.

\section{Availability of data and materials}

The datasets used and/or analyses during the current study are presented within the manuscript and available from the corresponding author on reasonable request.

\section{Declarations}

Ethics approval and consent to participate

Ethical approval was obtained from the institutional review board of Aksum University College of health science on 14 June 2020 with ethical number IRB 129/2020. Respondents have informed the purpose of the study, and then information was collected after obtaining written informed consent from each participant. Information was recorded anonymously and confidentiality was assured throughout the study period.

\section{Consent for publication}

Not applicable

\section{Competing interests}

The authors declare that they have no competing interest.

Received: 22 October 2020 Accepted: 10 June 2021

Published online: 21 June 2021

References

1. Zheng Y-Y, Ma Y-T, Zhang J-Y, Xie X. COVID-19 and the cardiovascular system. Nat Rev Cardiol. 2020;17(5):259-60. https://doi.org/10.1038/s41569020-0360-5.

2. Zu ZY, Jiang MD, Xu PP, Chen W, Ni QQ, Lu GM, et al. Coronavirus disease 2019 (COVID-19): a perspective from China. Radiology. 2020;296(2):E15-E25.

3. Dashraath P, Wong JU, Lim MXK, Lim LM, Li S, Biswas A, et al. Coronavirus disease 2019 (COVID-19) pandemic and pregnancy. American journal of obstetrics and gynecology. 2020;222(6):521-31.

4. Amanor-Boadu V, Ross K. COVID-19 incidence trends between April and June 2020: A global analysis. medRxiv. 2020. https://www.medrxiv.org/ content/10.1101/2020.07.07.20148007v1.

5. Nkengasong JN, Mankoula W. Looming threat of COVID-19 infection in Africa: act collectively, and fast. Lancet. 2020;395(10227):841-2. https://doi. org/10.1016/S0140-6736(20)30464-5.

6. Gilbert M, Pullano G, Pinotti F, Valdano E, Poletto C, Boëlle P-Y, et al. Preparedness and vulnerability of African countries against importations of COVID-19: a modelling study. Lancet. 2020;395(10227):871-7. https://doi. org/10.1016/S0140-6736(20)30411-6.

7. Achoki T, Alam U, Were L, Gebremedhin T, Senkubuge F, Lesego A, et al. COVID-19 pandemic in the African continent: forecasts of cumulative cases, new infections, and mortality. medRxiv. 2020. https://www.medrxiv.org/ content/10.1101/2020.04.09.20059154v3.

8. Mohammed H, Oljira L, Roba KT, Yimer G, Fekadu A, Manyazewal T. Containment of COVID-19 in Ethiopia and implications for tuberculosis care and research. Infect Dis Poverty. 2020;9(1):1-8.

9. Murthy S, Gomersall CD, Fowler RA. Care for critically ill patients with COVID-19. Jama. 2020;323(15):1499-500.

10. Geldsetzer P. Knowledge and perceptions of COVID-19 among the general public in the United States and the United Kingdom: a cross-sectional online survey. Annals of internal medicine. 2020;173(2):157-60.

11. Seid MA, Hussen MS. Knowledge and attitude towards antimicrobial resistance among final year undergraduate paramedical students at University of Gondar, Ethiopia. BMC Infect Dis. 2018;18(1):312. https://doi. org/10.1186/s12879-018-3199-1.

12. Zhang $M$, Zhou $M$, Tang F, Wang $Y$, Nie H, Zhang $L$, et al. Knowledge, attitude, and practice regarding COVID-19 among healthcare workers in Henan, China. Journal of Hospital Infection. 2020;105(2):183-7.

13. Huynh G, Nguyen TNH, Vo KN, Pham LA. Knowledge and attitude toward COVID-19 among healthcare workers at district 2 hospital, Ho Chi Minh City. Asian Pac J Trop Med. 2020;13(6):260. https://doi.org/10.4103/1995-7645.2 80396.

14. Taber KS. The use of Cronbach's alpha when developing and reporting research instruments in science education. Res Sci Educ. 2018;48(6):1273-96. https://doi.org/10.1007/s11165-016-9602-2.

15. Tesfaye B, Haile D, Lake B, Belachew T, Tesfaye T, Abera H. Uncontrolled hypertension and associated factors among adult hypertensive patients on 
follow-up at Jimma University teaching and specialized hospital: crosssectional study. Res Rep Clin Cardiol. 2017;8:21-9. https://doi.org/10.2147/ RRCC.S132126

16. Taghrir MH, Borazjani R, Shiraly R. COVID-19 and Iranian medical students; a survey on their related-knowledge, preventive behaviors and risk perception. Arch Iran Med. 2020;23(4):249-54. https://doi.org/10.34172/aim.2 020.06 .

17. Zhong B-L, Luo W, Li H-M, Zhang Q-Q, Liu X-G, Li W-T, et al. Knowledge, attitudes, and practices towards COVID-19 among Chinese residents during the rapid rise period of the COVID-19 outbreak: a quick online crosssectional survey. Int J Biol Sci. 2020;16(10):1745-52. https://doi.org/10.7150/ ijbs.45221.

18. Barnes DF, Golumbeanu R, Diaw I. Beyond electricity access: output-based aid and rural electrification in Ethiopia: World Bank; 2016. https://doi.org/1 $0.1596 / 26317$

19. Wolf MS, Serper M, Opsasnick L, O'Conor RM, Curtis LM, Benavente JY, et al. Awareness, attitudes, and actions related to COVID-19 among adults with chronic conditions at the onset of the US outbreak: a cross-sectional survey. Ann Intern Med. 2020;173(2):100-9. https://doi.org/10.7326/M20-1239.

20. Paul A, Sikdar D, Hossain MM, Amin MR, Deeba F, Mahanta J, et al. Knowledge, attitudes, and practices toward the novel coronavirus among Bangladeshis: implications for mitigation measures. PLoS One. 2020;15(9): e0238492. https://doi.org/10.1371/journal.pone.0238492.

21. Bhagavathula AS, Aldhaleei WA, Rahmani J, Mahabadi MA, Bandari DK Novel coronavirus (COVID-19) knowledge and perceptions: a survey on healthcare workers. MedRxiv. 2020. https://www.medrxiv.org/content/ medrxiv/early/2020/03/16/2020.03.09.20033381.full.pdf.

\section{Publisher's Note}

Springer Nature remains neutral with regard to jurisdictional claims in published maps and institutional affiliations.

Ready to submit your research? Choose BMC and benefit from:

- fast, convenient online submission

- thorough peer review by experienced researchers in your field

- rapid publication on acceptance

- support for research data, including large and complex data types

- gold Open Access which fosters wider collaboration and increased citations

- maximum visibility for your research: over $100 \mathrm{M}$ website views per year

At BMC, research is always in progress.

Learn more biomedcentral.com/submissions 